IZTOK OSTAN, Ph.D.

E-mail: iztok.ostan@fpp.uni-lj.si

University of Ljubljana, Faculty of Maritime Studies

and Transportation

Pot pomorščakov 4, 6320 Portorož, Slovenia

BORUT POLŠAK, Ph.D.

E-mail: borut.poljsak@zf.uni-lj.si

University of Ljubljana, Faculty of Health Studies

Poljanska cesta 26a, 1000 Ljubljana, Slovenia

EVA PODOVŠOVNIK AXELSSON, Ph.D.

E-mail: eva@martingolf.si

Independent researcher

Ivana Regenta 8, 6310 Izola, Slovenia
Human - Transport Interaction

Preliminary Communication

Accepted: Feb. 9, 2011

Approved: Dec. 20, 2011

\title{
MOTIVATIONS FOR HEALTHY LIFESTYLE IN RAILROAD EMPLOYEES
}

\section{ABSTRACT}

The aim of the paper is to present the results of a survey of railroad employees' motivation for a healthy lifestyle. For this purpose a specific questionnaire was developed. The study was performed on 245 Slovene railroad workers (168 of them blue-collar ones). The great majority (66.9\%) were found to be overweight or obese (BMI 25 or more), with no significant difference between blue- and white-collar workers. The great majority of them were in general aware of having unhealthy nutrition and an unhealthy lifestyle.

Most of the employees felt the need to improve (at least in part) their nutrition (74.7\%) and lifestyle (78.0\%); the majority (67.8\%) also declared that they could adopt a healthier lifestyle despite the constraints of everyday life and work conditions; however, $57.6 \%$ said that they had been already putting considerable effort into a healthier nutrition and lifestyle. Thus the effort needed to overcome constraints toward a healthier lifestyle seems to be the key problem: the majority (54.3\%) would rather choose walking than running or other intensive forms of exercise; they are not ready to do it for more than one hour per day (60\%), and they are not ready to give up permanently food that they like and that is considered unhealthy. The differences in motivations for a healthy lifestyle between blue- and white-collar workers were not significant at the 0.05 level.

Further research in this field is needed; however, it seems that the methods of efficient marginal modifications of lifestyle are required.

\section{KEYWORDS}

human resources management, railroad, blue-collar workers, white-collar workers, healthy lifestyle, motivations

\section{INTRODUCTION}

The term lifestyle refers to the way in which someone lives, including the place they live in, the things they own, the kind of job they do and the activities they enjoy [1]. In a broad sense lifestyle includes also one's beliefs. Berg [2] described two conceptions of lifestyle. In the first one it has three levels: values, attitudes and actions. In the second conception the lifestyle includes differences in the actions of everyday life. In the research of the relation between lifestyle and health, as herein, the term is used in a narrower sense: it is "usually restricted to individual habits, such as smoking, diet, physical exercise or alcohol consumption" [3]. In this paper the term healthy lifestyle will mean habits that promote individual's health and psycho-physical fitness.

There is wide scientific evidence of the positive effects of a healthy diet, regular exercise, rest and relaxation and other elements of a healthy lifestyle on health. A growing corpus of research shows that a worker's lifestyle has an important impact on the work process as well. A healthy lifestyle may reduce absenteeism and improve employee's performance [4]. Despite the fact that some empirical studies have not detected any association between lifestyle and job stress [5] there are many studies that have confirmed that a healthier lifestyle reduces occupational stress $[6,7,8]$. Unhealthy lifestyle practices like excessive alcohol consumption, sleepiness and others are known to increase the risk of work accidents. Since the human factor is the major cause of traffic accidents in most branches of transportation industries $[9,10,11]$ during recent decades the study of the relationship between lifestyle and transport operators' behaviour has 
received increasing interest from researchers [12]. The research into transportation industry managers' lifestyles has been expanding as well [4].

Healthy lifestyle is related to work safety. Unhealthy lifestyle might lead to the state of chronic stress. Symptoms of stress that increase the risk of work accidents are irritability, fatigue, headache, apathy, anxiety, dissatisfaction, depression, exaggeration, insomnia or sleepiness, exhaustion, and more [13]. Such physiological and psychological effects of stress might have particularly negative effects in traffic, where the problem of safety is of extreme importance. Many studies have demonstrated the importance and complexity of safety problems in the traffic of pedestrians [14] in road traffic $[15,16,17,18,19]$, rail $[20,21]$, maritime [22], and air traffic [23, 24], as well as other segments of transport systems.

Inquiries into public opinion in various countries demonstrate that "health" is among the most important declared values $[25,26,27]$. It would be expected that individuals are very motivated to maintain a healthy lifestyle; however, their real behaviour seems to run in opposition to this value. Paton [28] emphasised the importance of the problem quoting Shaun Matison (PruHealth manager): "Three-quarters of people see the health of themselves and their loved ones as a key priority but for the majority it would take a diagnosis of ill health to motivate any significant change of lifestyle". Because of shift work and travelling conditions bluecollar workers in transport industry have even more constraints from choosing a healthy lifestyle.

This was the key problem that a group of researchers at the University of Ljubljana were faced with. In 1995 a long-term project started, aimed at finding healthy lifestyle solutions suitable even for transportation industry workers. The project consisted of three main research/development activities:

a) A preliminary study (1995-2001). Its goal was to determine elements of lifestyle that are effective in promoting wellbeing, but also safe enough and simple to use even for transport operators. Besides theoretical study, this phase included researchers' personal experimental verification of different marginal changes of lifestyle elements. The results were published in a lifestyle manual [29].

b) Experiment MLC (Marginal Lifestyle Changes) began in 2004. Volunteers from the transport industry (shift work and frequent travels) and controls followed a three-week program of small changes in lifestyle. Its first phase was concluded in 2009. The results are not included in this paper.

c) Epidemiological research on lifestyle of employees in transport industry in Slovenia. The research started in 2007. Its main goal was to verify the readiness for healthier lifestyle on a representative sample of 1,116 persons employed in the Slovene transport industry.
The first phase of this epidemiological research was performed among railroad employees. The behaviour of this working group was poorly covered with empirical research, particularly regarding blue-collar workers. There were few studies of stress perception in railroad blue-collar workers. The pioneer research conducted by Barnes [30] on Indian railroad blue-collar workers showed that the level of perceived stress is high. The study of Diem [31] was focused on the effects of some stress moderators on stress perception (strain) of a special group of railroad workers railroad yardmasters. Our research on Slovene railroad employees seems to be the pioneer study on different aspects of their lifestyle healthiness. Its first results were published in 2011 [32].

\section{HYPOTHESES}

This article presents the results in attempting to verify two hypotheses:

Hypothesis 1: There is a significant difference in awareness of lifestyle unhealthiness between blueand white-collar workers.

Hypothesis 2: White-collar workers are readier for changes towards a healthier lifestyle than blue-collar workers.

\section{METHODS}

\subsection{Questionnaire and measures}

For this research a special (unique six pages long) anonymous questionnaire was developed. It was divided into seven sections (I - Demographic data, II - General state of health and satisfaction, III - Physical factors of health, IV - Nutrition, V - Other factors of health, $\mathrm{VI}$ - Valuation of proper lifestyle, VII - Improvement of lifestyle and nutritional habits).

Many particular lifestyle dimensions were measured; however, in this paper we will present just the values of BMI (Body Mass Index) as a combined measure of calorie intake and exercising. Considering that the conditions of being overweight and obese are today critical health risk factors [33, 34, 35] BMI might be considered an important indicator of lifestyle healthiness. We will inquire into the awareness of being overweight and obese, of the unhealthiness of nutrition and lifestyle with three measures that will be presented in a detailed way in the next section.

To measure the workers' motivations toward healthier nutrition and lifestyle the questionnaire contained 15 questions. The questions that will be treated in this paper are presented in a detailed manner in the next section. 


\subsection{Sample and data collection}

The sample was stratified. Through the help of the personnel office of the Slovene railway company the questionnaires were distributed to employees, chosen randomly from personnel lists. Each selected candidate received with the questionnaire a stamped envelope with the address of the research institute.

The data were collected in 2008. There were 245 valid answers received.

\subsection{Statistical analysis}

For statistical analyses the statistical program SPSS Ver.16 was used.

First, the variables were edited, coded and explored. Frequency tables, basic statistics, data distribution and correlation coefficients among a subset of indicators as a measure for data validity were used.

In the last stage we tested the research hypothesis using the bivariate (t-test) or multivariate (linear regression) statistical analyses.

\section{RESULTS}

\subsection{Demographic data}

Most of the (245) employees included in the sample were males (87.8\%). The average age was 40.6 years (range from 21 to 62 years). The group of whitecollar workers - employees who declared that they do mostly clerical work - included 77 members, and the group of blue-collar workers - 168. The typical educational level of blue-collar workers was 12 years of education (64.3\%), whilst among white-collar workers the most numerous were employees with 14 or more years of education (46.8\%).

\subsection{BMI values and perception of lifestyle healthiness}

The average BMI of the sample was 27.1 , which is above the upper limit of the normal range (18.5-24.9). No statistically significant differences at the 0.05 level between BMI of blue-collar workers (27.4) and white- collar workers (26.5) were found. Thus, the great majority (66.9\%) of employees were overweight or obese (BMI being 25 or above). These persons might be considered as having an unhealthy lifestyle - an imbalance between energy intake and physical activity.

However, are they aware of the problem? We measured their valuation of the lifestyle healthiness with three questions:

- How much food do you eat? (too much, right quantity, too little)

- How is your nutrition? (very healthy, healthy, partly healthy - partly unhealthy, unhealthy, very unhealthy)

- How is your lifestyle? (very healthy, healthy, partly healthy - partly unhealthy, unhealthy, very unhealthy).

The answers of overweight and obese workers to these questions are presented in Table 1 in dichotomised form.

Among the selected group of employees, in which all should be concerned with their too abundant diet, $58.5 \%$ said they eat the right quantity of food, some (3\%) even believing they do not eat enough. Out of these persons $24.4 \%$ considered that they have healthy nutrition, and $25.6 \%$ of them said they have a healthy lifestyle.

Thus, the majority of employees with a problematic lifestyle were not aware of the general level of unhealthiness of their nutrition and lifestyle. Still, there is not enough awareness of particular problems (like too high body mass). No statistically significant differences at the 0.05 level in this awareness were found between blue- and white-collar workers. Therefore, Hypothesis 1 was not confirmed.

\subsection{Limited motivation of white- and blue-collar workers for substantial changes of lifestyle}

The great majority of all interviewed employees were aware of having nutritional habits $(70.7 \%)$ or lifestyles $(67.8 \%)$ that are at least in part unhealthy. Do they feel the need to improve it? Are they ready to do something about it?

We inquired into these phenomena with the statements presented in Table 2, asking the employees to indicate how much they agree with them (possible an-

Table 1 - Valuation of overweight and obese railroad employees regarding their nutrition and lifestyle

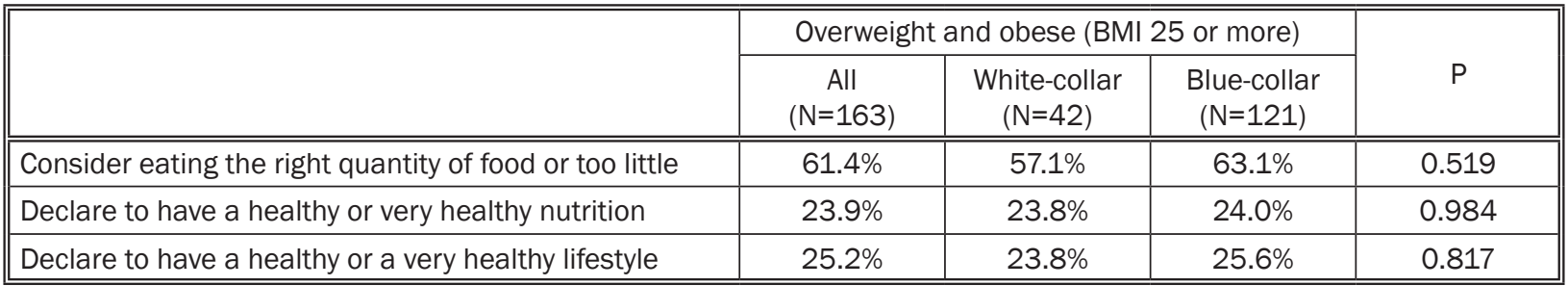

Note: * significant differences between white and blue-collar workers at the 0.05 level 
Table 2 - Motivations for healthier lifestyle

\begin{tabular}{|c|c|c|c|c|}
\hline & \multicolumn{3}{|c|}{ Agree or strongly agree } & \multirow[b]{2}{*}{$P$} \\
\hline & $\begin{array}{c}\text { All } \\
(\mathrm{N}=245)\end{array}$ & $\begin{array}{l}\text { White-collar } \\
\qquad(\mathrm{N}=77)\end{array}$ & $\begin{array}{l}\text { Blue-collar } \\
(\mathrm{N}=168)\end{array}$ & \\
\hline $\begin{array}{l}\text { I have already been endeavouring quite a while } \\
\text { for a healthier nutrition and lifestyle }\end{array}$ & $57.6 \%$ & $62.3 \%$ & $55.4 \%$ & 0.410 \\
\hline $\begin{array}{l}\text { Working and other obligations do not give me } \\
\text { much chance for a healthy lifestyle }\end{array}$ & $46.9 \%$ & $45.5 \%$ & $47.6 \%$ & 0.723 \\
\hline $\begin{array}{l}\text { Job and other living conditions do not give me } \\
\text { much chance for healthier nutrition. }\end{array}$ & $47.3 \%$ & $33.8 \%$ & $53.6 \%$ & $0.003 * *$ \\
\hline $\begin{array}{l}\text { I could do more to improve my } \\
\text { nutrition and healthy lifestyle. }\end{array}$ & $67.8 \%$ & $74.0 \%$ & $64.9 \%$ & 0.182 \\
\hline $\begin{array}{l}\text { As a matter of fact, as long as I am healthy, I am not ready to do } \\
\text { much to improve my nutrition and adopt a healthier lifestyle. }\end{array}$ & $31.4 \%$ & $26.0 \%$ & $33.9 \%$ & 0.182 \\
\hline $\begin{array}{l}\text { I prefer to integrate my diet with food supplements or } \\
\text { with small corrections that change my basic nutrition. }\end{array}$ & $23.3 \%$ & $20.8 \%$ & $24.4 \%$ & 0.571 \\
\hline $\begin{array}{l}\text { For improving my nutrition I would rather sacrifice } \\
\text { some of my money than my time and effort. }\end{array}$ & $23.0 \%$ & $19.7 \%$ & $24.6 \%$ & 0.385 \\
\hline $\begin{array}{l}\text { I would rather choose walking than running } \\
\text { (or other intensive forms of exercise). }\end{array}$ & $54.3 \%$ & $67.5 \%$ & $48.2 \%$ & $0.005 * *$ \\
\hline $\begin{array}{l}\text { My nutrition is healthy enough; therefore, I } \\
\text { do not feel the need to improve it. }\end{array}$ & $25.3 \%$ & $14.3 \%$ & $30.4 \%$ & $0.002 * *$ \\
\hline $\begin{array}{l}\text { My lifestyle is healthy enough; therefore, I } \\
\text { do not feel the need to improve it. }\end{array}$ & $22.0 \%$ & $11.7 \%$ & $26.8 \%$ & $0.002 * *$ \\
\hline
\end{tabular}

Note: ** significant difference at the 0.01 level;

swers: I strongly agree; I agree; I partly agree, I partly disagree; I disagree, I strongly disagree, I don't know).

Most of the employees declared that they are aware of the necessity to improve (at least in part) their nutrition $(74.7 \%)$. Significantly $(\mathrm{P}<0.01)$ more white-collar workers $(85.7 \%)$ than blue-collar ones $(69.6 \%)$ feel this necessity. Similar is their consciousness of the need for improvement (at least in part) of their lifestyle (78.0\%); also, in this respect, significantly $(P<0.01)$ more white-collar (88.3\%) than blue-collar (73.2\%) workers expressed this need.

The research results indicate that not the consciousness of the problem of lifestyle and unhealthy nutrition, but the effort needed to solve it, seems to be the key problem: $57.6 \%$ of the employees declared that they had already been putting considerable effort into healthy nutrition and lifestyle. In the group of white-collar workers the share of such persons was slightly higher $(62.4 \%)$ than among blue-collar workers $(56.4 \%)$, but the difference is not statistically significant at the 0.05 level. Considering that the results of these efforts are quite limited, there must be constraints that prevent achieving healthier nutrition and lifestyle. Constraints could be extrinsic (depending on the environment) or intrinsic (depending on the individuals themselves).

The analysis of the inquiry results shows that work conditions and other extrinsic factors play an important limiting role regarding a healthier lifestyle. A great part, but not the majority of employees, declared that their jobs and other living conditions do not give them much chance for a healthy lifestyle (46.9\%) and to partake of healthy food (47.3\%). In choosing healthy food white-collar workers experience less of such extrinsic constraints (33.8\%) than blue-collar workers (53.6\%). The difference is statistically significant at the 0.01 level. Also, in choosing a healthy lifestyle fewer white-collar (45.5\%) than blue-collar workers (47.6\%) declare that their jobs and other living conditions are an important limiting factor, but the difference is not statistically significant at the 0.05 level.

However, extrinsic conditions seem not to be an absolute limiting factor for a healthier lifestyle. Even among blue-collar workers $64.9 \%$ admitted that they "could do more for healthier nutrition and lifestyle". Among white-collar workers the relative percentage (74.0\%) was even higher although not significantly so $(P>0.05)$; thus, the average share of employees with such beliefs was quite high (67.8\%). If despite this the great majority do not do enough for their health, there must be intrinsic constraints preventing a healthier life as well.

In fact, most employees do not like intensive exercise. There were $54.3 \%$ who declared that they prefer walking to running, or other intensive types of exercise. Such preference is statistically significantly (at the 0.01 level), more present in clerical workers (67.5\%) than in blue-collar workers (48.3\%). Also, the time that 
they are ready to spend on exercising is for the majority limited. We asked the employees to indicate how much time they are ready to spend exercising during a working day ${ }^{1}$. On the average, a great majority (60\%) were ready to spend from 15 minutes to 1 hour per day for physical activities. No statistically significant differences at the 0.05 level were found between white-collar (58.4\%) and blue-collar workers (60.7\%) regarding this aspect.

Most workers were very reluctant to make major changes in their diet. It seems that direct pleasure in eating is more important than consciousness of negative health effects of certain diets. When asked whether they were ready to give up certain foods that they like, but know are harmful for their health ${ }^{2}$, just $6.9 \%$ of them replied that they would permanently give it up. No statistically significant difference at the 0.05 level was found in this respect between clerical workers (6.3\%) and blue-collar workers (7.1\%). There were $18.6 \%$ who would not change their diet at all unless they got ill. White-collar workers were found even more prone to such dietary conservativeness (22.2\%) than blue-collar workers (17.3\%), but the difference was not statistically significant at the 0.05 level. A great majority $(74.5 \%)$ would decrease the ingested quantity or give up their consumption at times. No statistically significant differences at the 0.05 level were found in this respect between white-collar (73.5\%) and blue-collar workers $(75.6 \%)$.

The results show that most white- and blue-collar workers are not ready to sensibly modify their lifestyles.

The analysis exposed some statistically significant differences between blue- and white-collar workers: despite having a similar (mostly unhealthy) lifestyle significantly more white-collar than blue-collar workers are aware of the necessity to improve at least in part their lifestyle and their diet. Blue-collar workers declare that they perceive more extrinsic constraints in choosing healthier nutrition. However, a significantly greater share of white-collar workers declared that they prefer just walking (not running) and were not ready to give up permanently food they like that is harmful for their health. Thus, Hypothesis 2 on greater motivation of white-collar workers for a healthier lifestyle was not confirmed.

\section{DISCUSSION}

The prevalent opinion among laymen and health researchers is that, "it is a lack of health self-awareness that is the key issue" [28] of low motivation for healthy lifestyle. We certainly do not deny the importance of knowledge and proper information for any kind of conscious activity, but we do question the importance of the awareness of health risks as a key motivational factor for a healthier lifestyle. For instance, among railway employees with higher levels of education (tertiary) only $8.1 \%$ (compared to $6.9 \%$ in the whole sample) were ready to give up totally the food items that they like but were harmful for their health. In many countries, governments promote higher consumption of fruits and vegetables through extensive campaigns for at least " 5 portions of fruits and vegetables per day"; however, without substantial success [36]. Some studies show that a large part of the population, even among overweight people, is aware of the importance of nutrition for their health. However, despite the awareness of health risks resulting from obesity, the majority is not willing to sensibly improve their diet [37].

As stated above, the effort needed to overcome intrinsic constraints for healthier lifestyles seems to be the key problem. The personal constraints might derive from two sources - from the acquired culture (bad habits) or they might be genetically based (instinctive). What we would like to stress is that in both cases it is very difficult to change the behavioural pattern:

- research on animals and humans shows that habits (nutritional, exercising and others) acquired in early youth are firmly encoded in the individual's biology through epigenetic markers and they are difficult to change during adulthood [38, 39, 40, $41,42,43,44,45]$. It has been shown experimentally on adult humans that having a different nutrition and lifestyle for only a few weeks changes the markers of more than 500 genes [46]; however, the drive of old habits is strong and the majority of adult population is reluctant to change.

- there is growing evidence that the drives for many unhealthy nutritional patterns are instinctive as well: wild animals, evidently acting solely on instinct without cultural effects, display tendencies similar to humans, damaging to their longevity: they tend to avoid healthy types of caloric restriction, prefer processed to raw food, and have an excessive intake of food stimulants and proteins when available [47, 48]. These nutritional tendencies confirm the Dawkins' theory of the selfish gene [49] as a part of the biological theory of imperfect adaptation of beings to the environment [50], which claims that animals in their instinctive behaviour tend toward gene reproduction that might be damaging to their healthy longevity. In fact, the amount of energy needed for reproduction is greater than for healthy longevity (caloric restriction); consuming processed food or food stimulants speeds up the release of energy that might be useful for immediate reproductive need (sexuality) and thus instinctively a biological advantage despite its damaging effects on long run health (see $[47,48]$ and references cited there). Instinctive drives do not determine the behaviour of humans; yet challenging them requires a lot of energy. 
Avoiding bad nutritional habits [51] and exercising [52] have been recognised as effective methods of health improvement and stress management, but require substantial effort. Exercising, for instance, has been found to be more effective than much easier adoptable stress management techniques like stress awareness and rational emotive behaviour therapy [53]. In the survey of stress prevention activities in 6,157 European Union companies it was found that nearly $40 \%$ of organisations had special polices on smoking and healthy diet, and $25 \%$ provided exercise facilities for their employees [53]. However, the longterm effects of the limited share of population that decide to improve substantially their lifestyle seems to be modest: according to an early review of studies [54], after a couple of years of healthy lifestyle $70 \%$ of individuals revert to their previous lifestyle habits.

\section{CONCLUSION}

The study among railroad employees has shown that the majority of employees feel the need for a healthier lifestyle; however, the majority is not motivated to significantly change their present lifestyle. Thus, methods of effective marginal modifications of lifestyle are required. The interviewed people declared interest in receiving more information on effective, easy-toadopt approaches toward improving lifestyle with diet $(50.6 \%)$ or physical factors of lifestyle $(57.6 \%)$. In the group of clerical workers the interest for such information was higher (51.9\% and $66.2 \%$, respectively) than in blue-collar workers $(50.0 \%$ and $53.6 \%$, respectively), but the difference in the two groups concerning easy-to-adopt nutritional techniques was not statistically significant.

\section{ACKNOWLEDGMENTS}

Special thanks to Rick Harsh for language help and to Maksimiljan Petek for help in data collection. This research received no specific grant from any funding agency in public, commercial or not-for-profit sectors. All authors contributed to this manuscript in equal parts. There are no conflicts of interest.

\section{Dr. IZTOK OSTAN}

E-mail: iztok.ostan@fpp.uni-lj.si

Univerza v Ljubljani, Fakulteta za pomorstvo in promet

Pot pomorščakov 4, 6320 Portorož, Slovenija

\section{Dr. BORUT POLJŠAK}

E-mail: borut.poljsak@zf.uni-lj.si

Univerza v Ljubljani, Zdravstvena fakulteta

Poljanska cesta 26a, 1000 Ljubljana, Slovenija

Dr. EVA PODOVŠOVNIK AXELSSON

E-mail: eva@martingolf.si

Ivana Regenta 8, 6310 Izola, Slovenija

\section{POVZETEK}

\section{MOTIVIRANOST ZAPOSLENIH NA ŽELEZNICI ZA ZDRAV NAČIN ŽIVLJENJA}

Namen članka je predstaviti rezultate raziskave motiviranosti zaposlenih na železnici za zdrav način življenja. $V$ ta namen je bil oblikovan poseben vprašalnik. Študija je bila opravljena na 245 slovenskih železničarjih (med njimi 168 "modrih ovratnikov"). Pri veliki večini (66.9\%) je bila ugotovljena prevelika telesna masa (BMI 25 ali več), pri čemer ni bilo statistično značilnih razlik med delavci $v$ belih in modrih ovratnikih. Med njimi se jih je velika večina $v$ splošnem zavedala, da imajo nezdravo prehrano in nezdrav način življenja.

Zaposleni so večinoma izrazili potrebo po (vsaj delnem) izboljšanju svoje prehrane (74.7\%) in načina življenja (78.0\%); večina (67.8\%) jih je tudi menila, da bi lahko izbrali bolj zdrav način življenja kljub omejitvam, ki jih narekujejo vsakdanje življenje in delovni pogoji, vendar jih 57.6\% trdi, da se že precej trudi za zdravo prehrano in zdrav način življenja. Zato se zdi, da je glavni problem za uveljavitev bolj zdravega načina življenja posameznikov napor, ki je za to potreben: večina $(54,3 \%)$ bi raje izbrala hojo kot tek ali druge intenzivne oblike telesnega gibanja; niso pripravljeni za to žrtvovati več kot eno uro na dan (60\%) in se niso pripravljeni trajno odreči hrani, ki jo imajo radi, a je škodljiva. Razlike $v$ motivacijah med fizičnimi in umskimi delavci niso statistično značilne pri 5\% tveganju.

Potrebno je nadaljnje proučevanje tega področja, vendar se zdi, da so potrebne učinkovite metode izboljšanja načina življenja, temelječe na majhnih spremembah življenjskega sloga.

\section{KLUUČNE BESEDE}

management človeških virov, železnice, fizični delavci, umski delavci, zdrav način življenja, motivacije

\section{REFERENCES}

1. The question asked was: "Exercising is important for preserving health; however, during the working week we have limited possibilities for it. How much time are you ready to spend at the most during the working day for exercising?" The possible answers: nothing, up to $15 \mathrm{~min}$, up to $30 \mathrm{~min}$, up to 1 hour, up to 1.5 hour, up to 2 hours, 2 hours or more.

2. The employees could choose several answers. The answers were: a) I am not ready to give it up, unless an illness forces me to. b) I am ready to give it up temporarily. c) I am ready to diminish the ingested quantity of such food. d) I am ready to give up permanently such food and to replace it with healthier ones.

\section{LITERATURE}

[1] Longman dictionary of contemporary English: Third edition, Longman Group Ltd., Essex, 1978/1995

[2] Berg, H.Y.: Understanding subgroups of novice drivers. A basis for increased safety and health. Ph.D. Thesis, Linköping University, Sweden, 2001 
[3] Chliaoutakis, J., Koukouli, S., Lajunen, T., \& Tzamalouka, G.: Lifestyle traits as predictors of driving behaviour in urban areas of Greece, Transportation research Part F. Traffic Psychology and Behaviour, Vol. 8, No. 6, 2005, pp. 413-428

[4] Tillmann, J.N., \& Beard, M.T.: Manager's Healthy Lifestyles, Coping Strategies, Job Stressors and Performance: An Occupational Stress Model, Journal of Theory Construction \& Testing, Vol. 5, No. 1, 2001, pp. 7-11

[5] Bugajska, J., Widerszal-Bazyl, M., Radkovicz, P., Pasierski, T., Szulczyk, G.A., Zabek, J., Wojciechowska, B., \& Jedryka-Goral, A.: Perceived work-related stress and early atherosclerotic changes in healthy employees, International Archives of Occupational \& Environmental Health, Vol. 81, No. 8, 2008, pp. 1037-1043

[6] DeFrank, R.S., Konopaske, R., \& Ivanchevich, J.M.: Executive travel stress: Perils of the road warrior, Academy of Management Executive, Vol. 14, No. 2, 2000, pp. 58-70

[7] Quick, J.C., Gavin, J.H., Cooper, C.I., \& Quick, J.D.: Executive health: building strength managing risks, Academy of Management Executive, Vol. 14, No. 2, 2000, pp. 34-43

[8] Neck, C.P., \& Cooper, K.H.: The fit executives: Health, stress, and success. Academy of Management Executive, Vol. 14, No. 29, 2000, pp. 107-121

[9] Dekker, S.: The field guide to understand human error, Ashgate Publishing Ltd., Aldershot, 2006

[10] Reason, J.: Managing the Risks of Organizational Accidents, Ashgate Publishing Ltd., Aldershot, 1997

[11] Strauch, B.: Investigating Human Error: Incidents, Accidents, and Complex Systems, Ashgate Publishing Ltd., Aldershot, 2002

[12] Gnardellis, C., Tzamalouka, G., Papadakai, M., \& Chliaoutakis, J.E.: An investigation of the effect of sleepiness, drowsy driving, and lifestyle on vehicle crashes, Transportation Research Part F: Traffic Psychology and Behaviour, Vol. 11, No. 4, 2008, pp. 270281

[13] Božič, Mija: Stres pri delu. Priporočnik za prepoznavanje in odpravljanje stresa pri delu poslovnih sekretarjev/ Stress at work: Manual for identification and elimination of stress in the work of business secretaries. Ljubljana: GV Izobraževanje, 2003

[14] Šimunović, L., Bošnjak, I., \& Mandžuka, S.: Intelligent Transport Systems and Pedestrian Traffic. Promet Traffic\&Transportation, Vol. 21, No. 2, 2009, pp. 141 152

[15] Tollazzi, T., Rencelj, M., \& Zalar, B.: Traffic Safety of Older Drivers in Various Types of Road Intersections. Promet - Traffic\&Transportation, Vol. 22, No. 3, 2010, pp. 193-201

[16] Muha, R., \& Sever, D.: Influence of Society Changes on the Model of Hazardous Goods Road Transportation. Promet - Traffic\&Transportation, Vol. 22, No. 2, 2010, pp. 133-142

[17] Vaziri, M., Fathi, M., \& Hoseini, S.M.S.: Controlling Longitudinal Safe Distance Between Vehicles. Promet Traffic\&Transportation, Vol. 21, No. 5, 2009, pp. 303310

[18] Alispahić, S., Antunović, Z., \& Becirović, E.: Training of Drivers in the Function of Road Traffic Safety. Promet -
Traffic\&Transportation, Vol. 19, No. 5, 2007, pp. 323327

[19] Kosor, D.: Increase of Air Traffic Safety in the Republic of Croatia Using New Methods of Analyzing Secondary Radar Parameters. Promet Traffic-Traffico, Vol. 11, Supplement No. 4, 1999, pp. 149-154

[20] Godec, A.: An Approach to the Safety Problem of Railway-Road Crossings in the Transport Systems. Promet Traffic-Traffico, Vol. 15, No. 5, 2003, pp. 299-306

[21] Mlakar, D., \& Sever, D.: Railway Traffic Management as a Function of the New Infrastructure Manager. Promet Traffic\&Transportation, Vol. 19, No. 6, 2007, pp. 387394

[22] Buksa, A., Segulja, I., \& Tomas, V.: Adjustment of Maintenance Approach for Improved Operability and Safety of Ship Navigation. Promet - Traffic\&Transportation, Vol. 22, No. 2, 2010, pp. 95-103

[23] Sumanovac, D.: Critical Situations and the Flight Safety System. Promet - Traffic\&Transportation, Vol. 20, No. 4, 2008, pp. 223-229

[24] Marušić, Z., Alfirević, I., \& Pita. O.: Maintenance Reliability Program as Essential Prerequisite of Flight Safety. Promet - Traffic\&Transportation, Vol. 21, No. 4, 2009, pp. 269-277

[25] Bond, M.H.: Finding Universal Dimensions of Individual Variation in Multicultural Studies of Values: The Rokeach and Chinese Value Surveys, Journal of personality and social psychology, Vol. 55, No. 6, 1988, pp. 1009-1015

[26] Musek, J.: Osebnost in vrednote/Personality and Values, Educy, Ljubljana, 1993

[27] Schwartz, S.H., \& Bilsky, W.: Toward a Theory of the Universal Content and Structure of Values: Extensions and Cross-Cultural Replications, Journal of personality and social psychology, Vol. 58, 1990, pp. 878-891

[28] Paton, N.: Unhealthy lifestyle choices on the up as downturn countries, Occupational health, Vol. 62, No. 6, pp. 7-7

[29] Ostan, I., Ambrozius, B., \& Ostan, A.: Osnove upravljanja s človeškimi viri (1.del): Ko zdravila odpovedo/ Basics of human resource management (Part 1): When drugs fail, Aura. Ljubljana, 2001

[30] Barnes, B. L. (1992). Stress in Transport Workers. Indian Journal of Clinical Psychology, 19, 14-17

[31] Diem, G. A.: Job stress in the transportation industry, Ph.D. Thesis, University of Denver, Denver, 2002

[32] Ostan, Iztok, Poljšak, Borut, Podovšovnik Axelsson, Eva (2011). Occupational Stress Perception and Healthy Lifestyle in Railroad Workers. Promet Traffic\&Transportation, Vol. 23, No. 3, 2011, pp. 195203

[33] Ravussin, E., \& Bouchard, C.: Human Genomics and Obesity: Finding Appropriate Drug Targets, European journal of clinical pharmacology, Vol. 410, 2000, pp. 131-145

[34] Seidell, J.C., \& Flegal, K.M.: Assessing Obesity: Classification and Epidemiology, British medical bulletin, Vol. 53, 1997, pp. 238-252

[35] Taubes, G.: An Obesity Rate Rise, Experts Struggle to Explain Why, Science, Vol. 280, 1998, pp. 1367-1368

[36] Food and Agriculture Organization/World Health Organization: Fruit and Vegetables for Health: Report 
of a Joint FAO/WHO Workshop, 1-3 September 2004, Kobe, Japan. 2004

[37] Kan, K., \& Tsai, W-D.: Obesity and Risk Knowledge, Journal of health economics, Vol. 23, 2004, pp. 907934

[38] Caldji, C., Diorio, J., \& Meaney, M.J.: Variations in Maternal Care in Infancy Regulate the Development of Stress Reactivity, Biological psychiatry, Vol. 48, 2000, pp. 1164-1174

[39] Francis, M., Diorio, J., Liu, D. et al.: Nongenomic Transmission Across Generations of Maternal Behavior and Stress Response in Rat. Science, No. 286, 1999, pp. 1155-1158

[40] Weaver, J.C.G., Cervoni, N., Champagne, F.A. et al.: Epigenetic Programming by Maternal Behaviour, Nature neuroscience, Vol. 7, No. 8, 2004, pp. 847-854

[41] DahIman, I., Linder, K., Arvidsson Nordström, E. et al.: Changes in Adipose Tissue Gene Expression with Energy-Restricted Diets in Obese Women, The American journal of clinical nutrition, No. 81, 2005, pp. 1275 1285

[42] Kallio, P., Kolehmainen, M., Laaksonen, D.E., Kekäläinen, J., et al.: Dietary Carbohydrates Modification Induces Alterations in Gene Expression in Abdominal Subcutaneous Adipose Tissue in Persons with the Metabolic Syndrome: The FUNGENUS Study, The American journal of clinical nutrition, No. 85, 2007, pp. 1417-24

[43] Zieker, D., Fehrenbach, E., Dietzsch, J. et al.: cDNA Microray Analysis Reveals Novel Candidate Genes Expressed in Human Peripheral Blood Following Exhaustive Exercise, Physiological genomics, No. 23, 2005, pp. 287-294

[44] Buttner, P., Mosing, S., Lechtermann, A. et al.: Exercise Affects the Gene Expression Profiles of Human White Blood Cells, Journal of applied physiology, No. 102 2007, pp. 26-36
[45] Connolly, P.H., Caiozzo, V.J., Zaldivar, F. et al.: Effects of Exercise on Gene Expression in Human Peripheral Blood Mononuclear Cells, Journal of applied physiology, No. 97, 2004, pp. 1461-1469

[46] Ornish, D., Magbanua, M.J.M., Weidner, G. et al.: Changes in Prostate Gene Expression in Men Undergoing an Intensive Nutrition and Lifestyle Intervention. Proceedings of the National Academy of Sciences of the United States of America, No. 105, 2008, pp. 8369-8374

[47] Ostan, I., Poljšak, B., Simčič, M., \& Tijskens, L.M.M.: Nutrition for the Selfish Gene, Trends in food science \& technology, Vol. 20, No. 8, 2009, pp. 313-374

[48] Ostan, I., Poljšak, B., Simčič, M., \& Tijskens, L.M.M.: Appetite for the selfish gene, Appetite. Vol. 54, No. 3, pp. 442-449

[49] Dawkins, R.: The Selfish Gene/Sebični gen, Mladinska knjiga, Ljubljana, 1976/2006

[50] Dawkins, R.: The Extended Phenotype: The Long Reach of the Gene, Oxford University Press, Oxford, New York, 1982/1999

[51] Lindquist, T.L., \& Cooper, C.L.: Using lifestyle and coping to reduce job stress and improve health in "at risk" office workers, Stress Medicine, Vol. 15, No. 3, 1999, pp. 143-153

[52] Cartwright, S., \& Cooper, C.: Individually targeted Interventions. In Barling, J., Kelloway, E.K., \& Frone, M.R. (Eds.), Handbook of work stress, Sage Publications, Thousand Oaks, London, New Delhi, 2005, pp. 607622

[53] Kompier, M., \& Cooper, C. (Eds.): Preventing stress, improving productivity: European case studies in the workplace, Routledge, London, 1999

[54] Ivanchevich, J., \& Matteson, M.T.: Organizational level stress management interventions: A review of recommendations, Journal of Organizational Behaviour Management, No. 8,1987 , pp. $229-248$ 